the losses incurred by Aventis, the company marketing the StarLink corn, is absurd. Both Aventis and the EPA can be faulted for pretending that corn grown for animal feed could be kept completely separate from corn grown for human consumption. But Aventis chose to market StarLink as animal feed only, rather than waiting to collect the additional data required by the EPA for approval as a food. The issue is not whether data ultimately showed any human food risk from StarLink (in fact, there appears to be no such risk). It is one of public confidence in the regulatory effectiveness of the EPA and in the company's compliance with the restrictions under which it agreed to operate.

Chapter 7 of the book boldly states that we now know that "recombinant DNA technology is among the safest technologies ever developed" - a broad and sweeping claim for a technology that is only a few decades old. In his recent review of Michael Crichton's novel State of Fear (Nature 433, 198; 2005), Myles Allen noted: "A hallmark of good science must be the way it treats uncertainty." In this, Fedoroff and Brown have not been as forthcoming as they should. As a plant breeder, I fully understand the frustration of scientists who are focused on the good that a tool such as genetic engineering can do. However, the agricultural and plantbreeding history that Fedoroff and Brown describe, with its theories that later proved untrue and its technologies that were harmful in unanticipated ways, suggests that a degree of humility would be appropriate. Just as opponents of genetic engineering are unaware of, or are loath to acknowledge, the aspects of this technology that we do understand, such as the genetic history of our cultivated plants, so proponents are reluctant to admit the ambiguities and unknowns about genetic engineering.

As a well-written, engaging account of a controversial subject from a scientist's viewpoint, Mendel in the Kitchen should be on the reading list for everyone interested in genetic engineering, both proponents and opponents. It assembles a large and informative body of information about many of the issues that have raised concerns about genetically engineered crops. However, although the authors state in their introductory chapter, "Which view will seem right to you depends on what you consider conventional, and on how you define the ways of nature," the rest of the book attempts to convince readers that only one view is right.

Margaret E. Smith is in the Department of Plant

Breeding and Genetics, Cornell University,

Ithaca, New York 14853, USA.

\section{More on food and genes}

Genes on the Menu: Facts for Knowledge-Based Decisions

by Paul Pechan \& Gert E. de Vries

Springer, $£ 23, \$ 39.95$, €29.95

\title{
Admitting sympathy beyond species
}

\section{Thinking with Animals: \\ New Perspectives on \\ Anthropomorphism \\ edited by Lorraine Daston \& \\ Gregg Mitman \\ Columbia University Press: 2005. 240 pp.

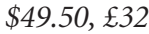

\section{Juliet Clutton-Brock}

When Konrad Lorenz began his studies of animal behaviour in the 1930s, thereby marking the beginnings of ethology as a science, he related the ways of his jackdaws to the ways of people and used highly personal and anthropocentric language. Then, from around the middle of the twentieth century, with the onset of behaviourism, any assumption that animals share the thoughts, feelings or motivations of humans began to be called anthropomorphism. It became a pejorative term applied to the ideas of anyone who dared to believe that animals were capable of conscious thought.

Over the past decades, with the expansion of knowledge about the behaviour of humans and animals, as well as an increased understanding of evolutionary theory, psychologists and philosophers have joined ethologists in research into the minds of animals. This research, known as cognitive ethology, has resulted in many investigations into consciousness, cognition, self-awareness and intelligence, as well as on whether animals feel pain, anger, fear or love, or have a theory of mind. In this context, the title of philosopher Thomas Nagel's essay "What is it like to be a bat?" (in Mortal Questions, Cambridge University Press, 1979) has been much quoted and paraphrased in the ethological literature, including this book.

With cognitive ethology has come the general realization that anthropomorphism does not necessarily disrupt scientific observation but can support the continuity between humans and animals. A strong supporter of this view is Frans de Waal, who proposes the term 'anthropodenial' for the rejection of shared characteristics between humans and animals (The Ape and the Sushi Master, Basic Books, 2001).

On the other hand, there are still those who maintain that anthropomorphism is a distraction from scientific rigour. Over half a century, J. S. Kennedy never wavered from his published view that "if the study of animal behaviour is to mature as a science, the process of liberation from the delusions of anthropomorphism must go on" (The New Anthropomorphism, Cambridge University Press, 1992).

All these points are cited and discussed in the nine eclectic essays in Thinking with
IMAGE UNAVAILABLE FOR COPYRIGHT REASONS

Rotating photographs of bats turns our perceptions about them upside-down.

Animals, many of which begin with a sentence such as "Anthropomorphism has long been considered a bad word in science". However, as the somewhat contentious title suggests, the main theme of the book is not a further discussion of the now rather jaded arguments for or against the humanizing of animals in science. Instead, it examines the actual practice of anthropomorphism in a wide variety of case studies.

One of the most impressive of these shows how taking an anthropocentric attitude to animals and treating them as individuals can have a dramatic effect on attitudes to animal conservation. In a fascinating account, Gregg Mitman outlines the management of elephants in Kenya. In the 1960s, when 'hard' science ruled, thousands of elephants were killed in order to keep the population within what was considered to be the carrying capacity of Kenya's national parks and reserves. Then, in the 1970s, came the work of Iain DouglasHamilton, followed by many others, to make the public aware of the social life of elephant families. This new perspective led directly to the promotion of the elephant as an endangered species and the banning of the ivory trade.

An essay by the film-maker Sarita Siegel describes how she made a documentary on the work of Anne Russon with orang-utan orphans. This demonstrates the importance for conservation of cooperation between the media and biologists with attitudes 


\section{Polluting utopia}

\section{The idyllic reputation of a lost island community may not be wholly deserved.}

\section{Andy Meharg}

The remotest occupied island in the British Isles, the Outer Hebridean outlier Hirta in the St Kilda archipelago, has become symbolic of a utopia corrupted by modern, capitalist society. Originally a self-sufficient and self-governing community, the islanders changed their aspirations as soon as they had regular contact with outside culture in the nineteenth century. They yearned to leave their sea-girt, lonely home, and Hirta was completely abandoned in 1930. The death of the island community was immortalized in Michael Powell's 1937 film The Edge of the World.

The island has long commanded the fascination of the British public. It was the subject of one of the most remarkable, and earliest, of British travelogues, Martin Martin's A Description of the Western Islands of Scotland, circa 1695, and his later A Voyage to St Kilda. Martin travelled at the behest of the Royal Society, recording Gaelic culture before the disruption that followed the Jacobite rebellion of 1745 . Unlike most early documenters of remote cultures, Martin was of the people, a Gael from the Hebridean island of Skye. His book inspired, among others, Samuel Johnson's A Journey to the Western Isles of Scotland.

The extent of anthropological study of the small St Kildan community is unparallelled, and has spawned a vast literature in the past 300 years. The documenters of island life were captivated by a culture solely dependent on the exploitation of seabirds, which were harvested for food, oil and feathers. They were also entranced by the island's remoteness and apparent independence. The archipelago's owner extracted a yearly rent. The island was self-sufficient and had no cash economy. It had a 'parliament' that met every day to take democratic decisions affecting the life of the community. A rotation of land stewardship ensured fairness in resource allocation, like the "anarcho-syndicalist commune" of Monty Python and the Holy Grail. Many nineteenth- and twentieth-century chroniclers have described the island as a utopia, including John MacCulloch, who wrote of his 1815 visit: "If this island is not the Eutopia so long thought, where will it be found? Where is the land which has neither arms, money, law, physic, politics, nor taxes?"

that, although they are anthropomorphic, are based on sound science.

The other seven essays are on widely different topics, from Wendy Doniger on zoomorphism in Indian Sanskrit texts to Paul White on the experimental animal in Victorian Britain. Cheryce Kramer discusses the ways in which Tim Flach manipulates his photographs to change our perceptions of animals: for example, his photos of bats are printed so that the animals appear to be

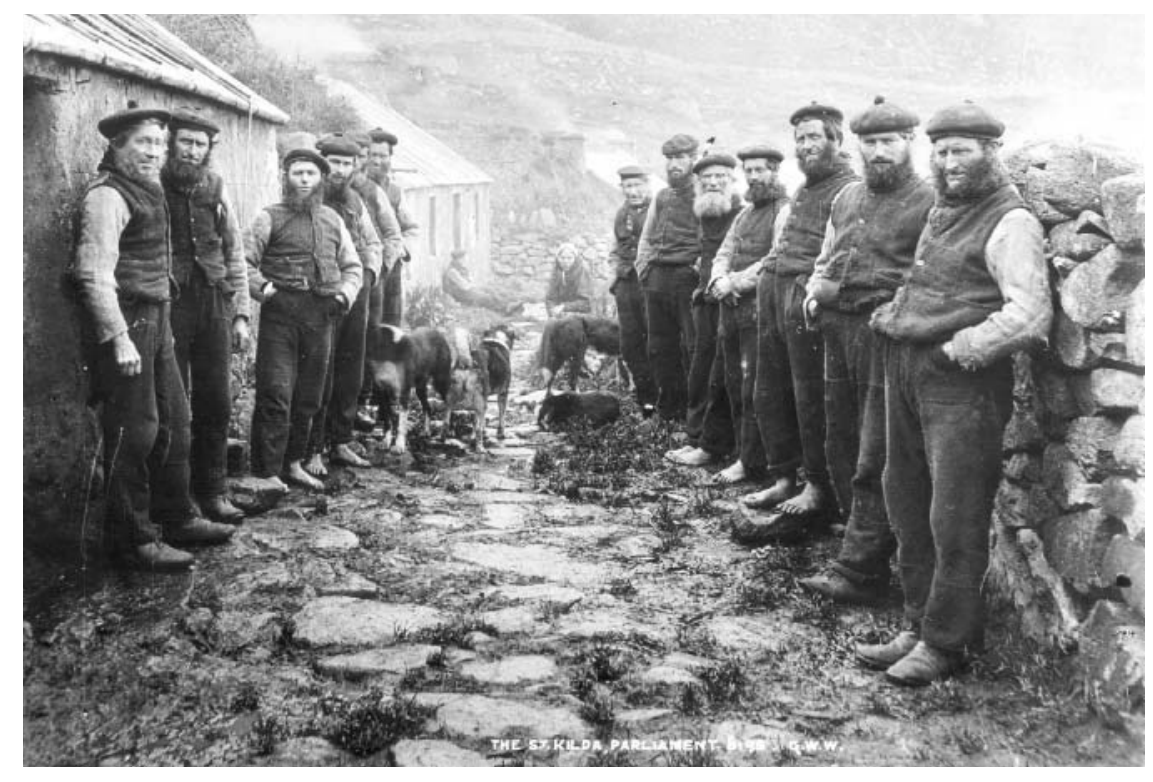

Paradise lost: the inhabitants of Hirta contaminated their island by overexploiting seabirds.

The Hirta community is now an iconic image for a devolved Scotland with a strong socialist tradition. The architect Enric Miralle's design for the new Scottish parliament drew inspiration from the St Kildan parliament, incorporating the forms of upturned keels of boats as a representation of the island's life.

But this utopia is a myth. The St Kildans' bird culture had severe effects on European seabird populations. Most notably, the islanders beat to death the last observed great auk in Britain, which they held to be a witch, in 1840, just before the global extinction of the species. My own research has thrown some light on the ecological balance of the island, showing that agronomic practices led to severe pollution of the arable land.

According to Martin, the St Kildans recycled all their wastes - faeces, peat ash, and bird guts and bones - applying them to their arable land as fertilizer. When I analysed these arable soils they were highly contaminated with lead, zinc and dioxins (Nature 421, 909-910; 2003). By analysing the lead isotopic composition of the arable soil, archaeological and modern seabird bones, and ancient peat ash from dwelling floors, I worked out that this pollution was coming from peat ash

standing upright, rather than hanging down, so they look like standing people. Sandra Mitchell asks: "What is the fate of anthropomorphism in contemporary science?" and argues that evidence is difficult to obtain, either way, for whether there are cognitive similarities between humans and animals. James Serpell writes about how thinking of animal companions in human terms is responsible for many of the benefits that their owners derive from them, such as the and bird bones in the compost stream. This pollution of arable soils is, to date, unique in terms of ancient settlements and was included in the case made to UNESCO (the United Nations Educational, Scientific and Cultural Organization) by the National Trust for Scotland (the archipelago's current owner) for extending St Kilda's World Heritage Site status for natural and marine environments to include the cultural landscape. The UNESCO committee will consider the proposal in June. Pollutant levels are so high, with lead and zinc concentrations in arable soils reaching $500 \mathrm{mg}$ per $\mathrm{kg}$, that they compare with the soils of Britain's most polluted industrial cities.

The pollution arose because this small island, with only 40 acres of arable land, has supported a relatively large population of around 200 inhabitants at least since the Iron Age. The island could sustain such a population only because the inhabitants acquired their protein from massive exploitation of seabird colonies. The accretion of human waste streams over the millennia has resulted in the polluted soil. Very far from paradise. Andy Meharg is in the School of Biological Sciences, University of Aberdeen, CruickshankBuilding, Aberdeen AB243UU, UK.

apparent love and loyalty of dogs. For the dogs, however, anthropomorphic intervention such as the docking of tails cannot be condoned, he argues.

Thinking with Animals is an unusual book that will surely join the growing literature on consciousness, animal cognition and the continuity between human and animal minds.

Juliet Clutton-Brock, South Barn, High Street,

Fen Ditton, Cambridgeshire CB5 8ST, UK. 